\title{
United States Budget Deficit: Considerations for a Social Security Reform
}

\author{
Natalia Victorovna Kuznetsova ${ }^{1}$ \& Ekaterina Vasilievna Kuznetsova ${ }^{2}$ \\ ${ }^{1}$ Department of World Economy, School of Economics and Management, Far Eastern Federal University, \\ Vladivostok, Suhanova St. 8, Russian Federation \\ ${ }^{2}$ National Security and Public Safety, Russian Federation \\ Correspondence: Natalia Victorovna Kuznetsova, Department of World Economy, School of Economics and \\ Management, Far Eastern Federal University, 690950, Vladivostok, Suhanova St. 8, Russian Federation. E-mail: \\ ipatovanat@mail.ru
}

Received: July 25, 2014 Accepted: August 15, 2014 Online Published: November 27, 2014

doi:10.5539/ass.v10n24p85 URL: http://dx.doi.org/10.5539/ass.v10n24p85

\begin{abstract}
This article analyses United States deficit and Social Security as the sole largest program of U.S. government. Forecast of future spending, receipts, and national debt exposes the necessity for a serious system change within domestic social security net. In particular, Social Security and retirement system of the United States is jeopardized in the nearest future because of the growing population of retirees-baby boomers.

The article proves Social Security's contribution to U.S. public debt, arguing that Social Security's future deficit must not be omitted. The article argues that the current employment rates that provide tax for Social Security cannot back it up putting both younger generation and retirees in a vulnerable position. Thus, the sustainability of Social Security must be restored based on more proper projection tools available nowadays.
\end{abstract}

Keywords: United States, deficit, debt, debt held by the public, governmental spending, outlays, tax revenue, receipts, the defense budget, social security, reform, baby boomers, aging, payroll tax, retirement benefits, super-committee, unsustainable, New Deal, Medicare, healthcare reform

\section{Introduction}

The projections of the government spending show that United States will keep spending more than receiving in tax revenues. While economists, politicians, and the general public agree that such development is disastrous for the economy of the United States, there is no common agreement on measures against it. While the U.S. government is working towards healthcare reform, the debates over Social Security continue. All attempts to reach a common conclusion fail because no social or political group is willing to compromise over their interests. In addition, there is a firm believe that Social Security reform is not a priority because it does not add to the public debt.

In considerations for government spending, the defense budget becomes a common target as a panacea against enormous national debt, however unsustainability of domestic Social Security net programs is often ignored. It is undeniable that decision-making in attempts to decrease the deficit and national debt must consider all the aspects, including healthcare and defense budget. However, the fact that United States citizens have enjoyed one of the most generous socio-economic safety nets in the world cannot be denied as well. The time has come to make difficult and politically unpopular decisions and ultimately got out of the vicious circle of unsustainable programs and irresponsible spending that decrease economic growth and potential ability to react better on any crisis: political, security, or economic. One of those politically unpopular decisions would be the Social Security reform.

\section{Methods}

Methodology for analysis of main contributing components to United States deficit and closer examination of Social Security's future deficit (as prognosed) includes collection and analysis of statistical data that includes governmental spending, unemployment statistics, demographics, and various projections. The article uses statistics from United States Department of Labor, White House, United States Treasury Department, United States Census Bureau, World Factbook, and also findings and opinions made by separate authors. The article 
relies on findings and forecasts made by Congressional Budget Office. Important explanation by Congressional Research Center's Nuschler and Sidor contributed to a final conclusion about necessity to include Social Security when considering growing American debt.

The analysis includes several stages. At the first stage United States deficit is examined, the largest components that contribute to it are being pointed out. Social Security is analyzed more closely and a large gap in future receipts and outlays is discovered, pointing to Social Security as a major source of future governmental spending (if laws remain unchanged), especially considering its mandatory nature. Second stage includes closer examination of Social Security's future deficit: growing retiring population (baby boomers), labor force participation rates and unemployment, brief review of American retirement system. Third stage provides overview of past attempts to fix Social Security, opinions about current stage, and options for future change. In the final stage (the discussion): the overview of U.S. national debt is presented; a myth that Social Security, as an off-budget program cannot contribute to the growing American debt is being argued by the authors using supportive opinions; growing U.S. public debt is being analyzed and Social Security is pointed out as one of the major contributor of future public debt (along with major Healthcare programs).

\section{3. results}

In the plainest definition budget deficit is an excess of government spending over government receipts (Mankiw, 2008b).

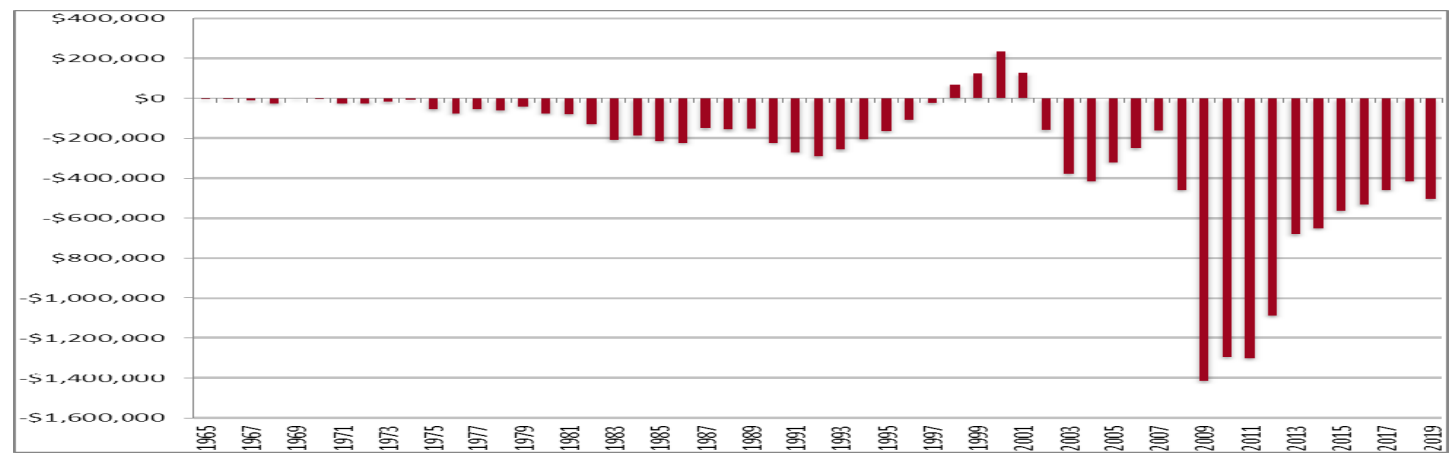

Figure 1. Deficit and Surplus of United States of America (in millions of dollars). Starting 2014 given is an estimate. ("Fiscal Year 2015. Historical Tables: Budget of the U.S. Government," n. d.)

In 2013 U.S. deficit fell 37\% compared to 2012 (Figure 1). The estimated deficit for 2014 is 648,805 million dollars, and it will keep decreasing for the next five years with an estimated increase in 2019. The reason for such drastic fall is that the government managed to collect more receipts comparing to the previous year, spending budget decreased, but it is estimated that this trend will not continue over the next years. It is estimated that government will manage to keep the deficit at a "stable" rate compared to previous years only because of the increase in receipts, and the spending will continue to grow ("Fiscal Year 2015. Historical Tables: Budget of the U.S. Government," n. d.). Stability of U.S. deficit is historically affected by the constant growing needs of the country on international and domestic arena. Analyzing data from 1940, with only few years of exceptions, spending of the country kept growing while the receipts were not always managed in accordance with spending. From 1940 outlays increased from 9,468 millions of dollars to 3,454,605 millions of dollars, while receipts increased from 6,548 to 2,775,103. The largest deficit the country has faced was in 2009 (in the midst of crisis), when receipts fell 17 percent and spending increased 18 percent, the deficit amounted to -1,412,688 of millions of dollars. The largest surplus ever recorded (since 1940) was in 2000, when surplus amounted to 236,241 millions of dollars, when receipts increased 11 percent, and outlays increased 5 percent. Commonly the deficit is blamed on ever-increasing national defense budget. The national defense budget increased significantly during Second World War and started to decrease since 1946 falling to 9,105 millions of dollars in 1948. However, the growing presence of U.S. on the international arena forced the defense budget to grow; in 1952 (with the start of the Cold War) it doubled, amounting to 46,266 millions of dollars. Then, from 1980 to 1986 it kept increasing average 20,000 millions of dollars per year, amounting already to 281,996 in 1987. For a decade, with the begin of the War on Terrorism the national defense budget started to increase most significantly that it has ever been recorded in the U.S. history, from 304,732 million in 2001 to 705,554 million in 2011, by 2013 government managed to decrease budget to 633,385 million of dollars, with estimates to decrease it to 585,786 by 2019 . 
Following the complaints about large national defense budget the only way for U.S. government to fix the deficit problem would be to completely get rid of national defense as a sector of country's structure.

The largest parts of U.S. deficit consist of, as of 2013, spending on Social Security-813,551 millions of dollars, then national defense budget-633,385, income security-536,511, Medicare-497,826, and health sector-358,315 millions of dollars. It is estimated that by 2019 Social Security spending will be 1,131,060 millions of dollars.

Spending on Social Security has been growing gradually and jumped to increase in early $70^{\text {th }}$. From 80 s to 2000 spending on Social Security roughly averaged 15,000 millions of dollars in increase per year, from 118,547 in 1980 to 409,423 in 2000. Starting an alarming growth since 2000, U.S. experienced the biggest increase so far of 6 percent in 2012. The estimated increase in social security spending in 2019 amounts to 1,131,060 millions of dollars.

Social Security is the largest federal government's program. 58 million people receive Social Security benefits, 70 percent out of which are retired workers (or their spouses and children), 11 percent are survivors of deceased workers, and 19 percent are disabled workers or their spouses and children (Congressional Budget Office (CBO), 2013a. Payroll taxes (roughly 96 percent of revenues) and income taxes on benefits (4 percent) are two primary sources of tax revenues for Social Security. Revenues, along with intergovernmental interest payments, are credited to two trust funds, collectively known as OASDI trust funds (Old-Age, Survivors, and Disability Insurance). The Figure 2 shows Social Security revenues and outlays with projections compiled by Congressional Budget Office. Revenues include payroll taxes and income taxes on benefits, and for 2011 and 2012 reimbursements from U.S. Treasury's general fund to make up for deficit in payroll taxes during those years, outlays include scheduled benefits and administrative costs.

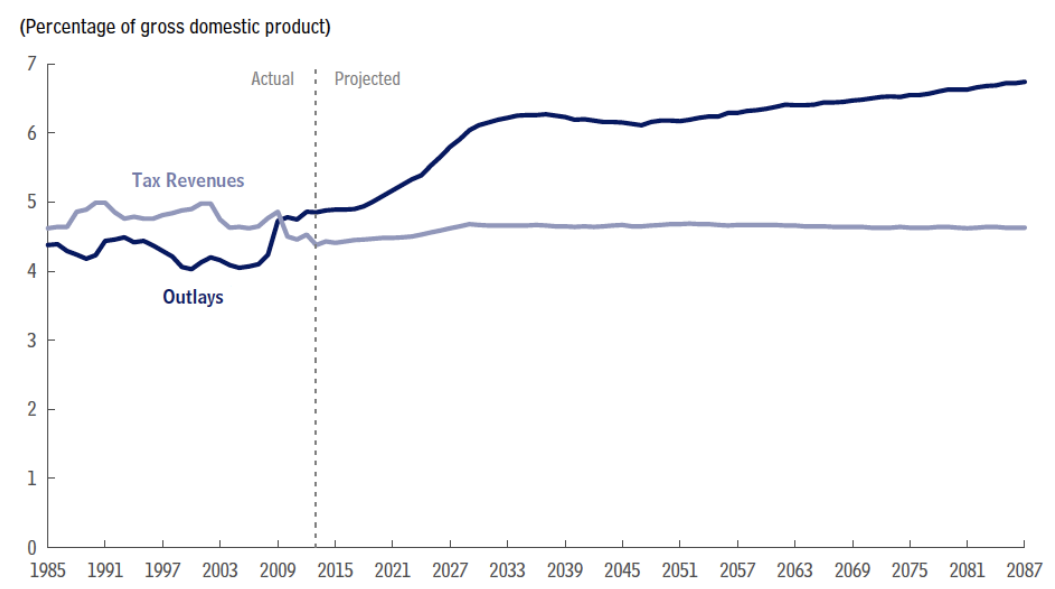

Figure 2. Social security tax revenues and outlays, with scheduled benefits (CBO, 2013a, p. 6)

As it can be seen in the illustration, the gap between social security's outlays and receipts will continue to grow significantly. CBO projects that there will be a 12 percent gap over the next 10 years, explaining that with the retiring baby-boom generation. The problem will only get worse in future, as retired baby-boomers will cause outlays to increase while leaving tax revenues remain almost constant. CBO projects that Disability Insurance trust fund will be exhausted in 2017, and Old-Age and Survivors Insurance trust fund will be exhausted in 2033. Thus, with the exhaustion of a short-term surplus of funds, payable benefits will be smaller than scheduled benefits.

Social Security system began its rise in 1930s as a part of New Deal program. The welfare relief and social assistance was very much needed by growing poor (and very often discriminated-black, women, immigrants) population. The need for such program became especially obvious in the midst of Great Depression and growing socialist challenge, when people started to get more and more disappointed in righteousness of capitalist social-economic structure. Opponents of Social Security warned that it would destroy private pensions. Franklin Roosevelt however believed that the legislation was "the capacity of industry to assume financial responsibilities and the fundamental necessity of proceeding in a manner that will merit the enthusiastic support of citizens of all sorts;" addressing breakouts of poverty and civil unrest he argued that, "we pay now for the dreadful consequence of economic insecurity-and dearly. We cannot afford to neglect the plain duty before us." (as cited in Altman, 2009) Thus the Social Security Act was signed into law and the prototype of modern social security 
system started to work.

However soon price of government's commitment to secure its citizens became too high, pointing out obvious loopholes in sustainability of mandatory entitlement programs such as Social Security. Numbers show that ability to pay for Social Security program is rapidly declining. There are two sides of the medal: apparent failure of the system to sustain itself and the lacking ability of the current economic conditions to back up that system (considering its direct dependence on the amount of taxes collected from working population).

As of July 2014, estimated average labor force participation rate is 62.9 percent, this number represents working-age Americans who have a job or actively seeking a job. This number is the lowest since 1977, when average yearly participation rate was 62.2 ("Labor Force Participation Rate 1977 to 2014," n. d.). Since 1977 U.S. population grew 30.9 percent (from 220,239,425 to estimated 318,892,103 in 2014) (Central Intelligence Agency, n. d.; "Population Estimates: Pre-1980: National Tables," n. d.; "Population Estimates: National Characteristics: Vintage 2013," n. d.).

Since 1977 to 2013, the population of 66 (full retirement age is between 65 and 67) and older almost doubled, growing 46.5 percent ("Population Estimates: Pre-1980: National Tables," n. d.; "Population Estimates: National Characteristics: Vintage 2013," n. d.), which also influences labor participation rate, given retired people more likely not to have a job. With that, starts a significant debate that cannot be ignored-whether decline in labor is more of the result of masse retirees, which almost cannot be fixed regardless of economic situation or the problem comes from young people failing to enter the workforce and general discouragement.

It is argued that, actually, participation rate of those who are 55 years old and older has been rising since 2003, whereas for those aged from 16 to 54 it is dropping, especially for people in 16 to 24 age category, which is proved by data provided by Bureau of Labor Statistics (Romano, 2014; "Employment Labor Projections," 2013).

There are multiple theories why this is happening. Urban Institute's authors suggest that same drop in labor force participation during and after Great Recession was caused by decrease in labor force entry (rather than share of people who are leaving labor force) and the share discouraged workers who stop looking for a job after numerous failed attempts to find it (Nichols \& Lindner, 2013). They also suggests that workers are less likely to re-enter the workforce (after leaving it) today than in the past, younger women have become less likely to enter that labor force than ten years ago, also people remain in school longer. On the opposite Boston Fed's authors argue that labor force participation for prime age adults declined from 2008 to 2013, given that this demographic group has been stable, as a consequence of large and persistent decrease in labor demand in post-Recession times (Erceg \& Levin, 2013).

In the post crisis economy there are fewer job openings and real economic growth is too slow to create enough jobs. Some also argue that corporate taxes are too high to create enough jobs. It is also argued that moving manufacturing to low-cost countries are taking away jobs from U.S., because of the cost advantage, though in the past few years more reshoring has been observed (manufacturers move job back from low cost countries to local development markets), it is likely that the trend of moving manufacturing overseas will continue (Weissmann, 2012). One of the most important debates is possibility of structural unemployment in the U.S., which is caused by geography, demography, or skills-for example, mismatch between available skills and skills that are in demand.

Whatever reasons there are behind unemployment rate in U.S., it is clear that there are not enough jobs and taxes to sustain the future deficit of Social Security. Responding to the crisis will either come down to raising taxes or tightening the belt-lowering the benefits.

It is argued that today's seniors and disabled are already falling behind the general population suggesting expansion of Social Security benefits. On the contrary, Schnieber (2012) argues that "today's retirees better off than the rest of the population; on average, they are more insulated from vagaries of a volatile economy," suggesting results of the study by Pew Research Center that revealed that after recession fewer people aged 65 and older had to cut on spending than those aged from 18 to 49 or those 50 to 64 (pp. 5-6). He also quotes Paul Samuelson, Noble Prize winner, who in 1967 called Social Security "the greatest Ponzi scheme ever contrived" (as cited in Schieber, 2012, p. 11). Schieber (2012) explained: "Most of my aunts and uncles retired in the 1970s, after having paid into the system for 20 to 25 years at extremely low payroll tax rates compared with the current levels" (p. 10).

American retirement consists of many options divided into two major categories: defined contribution plan and defined benefit (pension) plan. 
With defined contribution (DC) plan participant gets an account and his or her benefits are based on the amount of pre-tax contributions and any investment earnings made on money in the account. This plan includes plans like 401(k), profit sharing plans, employee stock ownership plans, etc.

Defined benefit plan (DB) is traditional pension plans where benefits are calculated with a fixed formula based on employee earnings history, service, and age, and are paid from a trust fund. There are also hybrid plans offered to employees.

More employers today are replacing DB plans with DC plans, in which the responsibility is mostly shifted to an employee: he or she decides how much contribution is enough and how to invest the assets. In this case participant's decisions are extremely important. In addition the investment risk is shifted from corporations to households exposing them to the risk of financial markets, making their retirement more vulnerable.

DC is not predetermined final retirement benefit; instead it depends on how much contributed in the employee's individual fund and how well the pension fund investments will perform. Thus employee has all the risk for his or her pension investment. There is a limit however set by the government how much of money can be contributed to such individual account.

Many employers freeze DB and offer DC instead, primarily due to expense and long term obligations associated with DB. In many DB plans the employer bears the investment risk and can either benefit from it or the opposite. It is an employer who makes a promise to pay certain amount of money in the future so it is employer who takes the risk of value fluctuations of the contributions. With DB employer must make sure there is enough money in the plan to pay off the promised benefits. Federal government steps in if the business fails to meet its obligation, that is the point of insured pension through DB, however that is also not guarantee that benefits will be received in the amount expected ("Understanding Defined Benefit and Defined Contribution Plans," 2014).

Considering that in future both promised benefits might be reduced and payroll taxes higher, it is logical that there will be increasing role of personal savings and individual retirement accounts, which not everybody has an access to.

The biggest difference is that DB pension will provide income until death (which makes it more difficult to calculate especially because today because of the better healthcare people live longer) and DC operates more like a saving account where when money run out, the retirees income from that account stops. DB funds are managed professionally, which is not always a case with DC.

According to Bureau of labor Statistics, only 59 percent of private industry workers have access to defined contribution plan, and 19 percent have access to defined benefits plan; the statistics is even more gruesome for low-income households ("Employee Benefits," n. d.). For a lot of people retirement is still a luxury. For those that are luckier but less fortunate Social Security is the only stability they can count on.

Social Security tax and predetermined retirement benefits are calculated with very complicated formula that ideally must consider how much money a worker will contribute to a fund and how much money considering inflation, health and life expectancy, wages, consumer price index, that worker (or a beneficiary) will receive in his or her benefits. Ideally the system should be self-sufficient, and must not be based on a promise but on guaranteed calculation. In this idealistic and very much simplified situation there is no deficit of social security trust funds-only temporary surplus.

In the reality the formula is complicated in many ways, but of course not perfect. There was a surplus for the most of the time with the exception of a temporary crisis in 1980s, however that surplus was not actually "saved"-both of these issues we discuss further down. The way Social Security works today, even imagining greater surplus, the forecast shows that the system will not be able to sustain for longer. Though it is hard to predict everything (for example, it is hard to predict slower economic growth and crisis), the formula still must be as close to the reality as possible.

In essence social security is just bookkeeping record on individual's earnings and payroll taxes based on a formula that has nothing to do with reality. As David John (2005) of the Heritage Foundation explains: "In reality, the Social Security trust funds contain nothing more than IOUs that have no value beyond a promise to impose higher taxes on future workers" (p. 4).

In the most current National Security Strategy (2010) it was made clear that the burden of the debt is felt heavily and that the vision of building a stronger foundation for economic growth in America lies in balancing priorities in managing the Federal Budget, reforming financial system, and shifting to greater domestic demand abroad. It is widely acknowledged that rising deficit and national debt is primarily driven by mandatory entitlement programs specifically, Social Security, Medicare, Medicaid, and Obamacare (Chougule, 2014). 
In 2011, President Barack Obama decided not to include Social Security reform in recommendations to Congress deficit super-committee that discussed deficit reduction measures, despite previous aspirations to discuss possible lower level of benefits to be paid over time. As the White House spokeswoman Amy Brundage explained: "...The president ... does not believe that Social Security is a driver of our near and medium term deficits" (as cited in Stein, 2011)

Instead, Democrats initially proposed a 2.5 to 3 trillion dollars deficit reduction plan (over the next 10 years) evenly split between tax increases (1.3 trillion in tax revenues) and spending cuts (Khimm, 2011). The cuts included 500 billion in savings from health programs (Medicare, Medicaid, etc.) and 400 billion from appropriations (half from defense), and 250 billion from benefits like federal-worker pension plans and farm subsidies. The plan also proposed more than 300 billion dollars in additional economic stimulus, including Social Security savings through using a new formula that calculates increase in cost of living. Republicans responded with a 2.2 trillion deficit reduction plan, that did not include new revenue through taxes, but it included: 440 billion of dollars raised through higher government fees, Medicare co-pays and/or Medicare premiums for wealthier beneficiaries; 200 billion assumed in additional revenue through economic growth the would result from tax reform. The spending cuts part included 700 billion from Medicare and Medicaid and $\$ 250$ billion through reducing government personnel. Also Republicans agreed on Social Security savings through recalculating the cost of living increase. After attempts to negotiate the plan, November 21, 2011, Joint Select Committee on Deficit Reduction (2011) issued a statement: "Despite our inability to bridge the committee's significant differences, we end this process united in our belief that the nation's fiscal crisis must be addressed and that we cannot leave it for the next generation to solve. We remain hopeful that Congress can build on this committee's work and can find a way to tackle this issue in a way that works for the American people and our economy."

Thus committee terminated it work without any outcomes unable to come to common conclusion. The agony of the situation continued in budget sequestration in 2013 (as part of a Budget Control Act of 2011, enforced in order to avoid default caused by the debt-ceiling crisis), split between defense and non-defense budgets (programs like Social Security, Medicaid, federal pay and veterans' benefits are exempted from the automatic spending cuts). However such measures, especially along with higher taxes may slow down economic growth and even lead to a new recession. While demands to end sequestration (arguing that it jeopardizes national defense and domestic security) continue, the fears are voiced over possible changes to social safety net programs, including possible transition to a Chained Consumer Price Index that calculates retirement benefits for social security differently, thus likely making them smaller. Unfortunately the majority of committee's working documents were not published, and for different socio-economic groups the priorities will differ.

November 2013 Congressional Budget office published a compendium of 103 options for reducing federal spending and increasing revenues over the next 10 years (although many of the options will have a long term effect), till 2023 (CBO, 2013b). CBO suggests to weight all the factors in decision making process, like how much deficit reduction is necessary, what type of changes would enhance economic growth, implications and burdens of changes, and negative consequences of cutting federal spending and rating taxes such as little time left for people planning and dangers of output and employment (and thus economy's growth) even further below its potential level (especially considering it is very far below now). Among 28 suggested discretionary spending options totaled in up to 1,252 billions of dollars in potential savings, the largest option is reducing the size of the military (potential 495 billions of dollars in savings), followed by reducing funding for international affairs programs (114), elimination of human space exploration programs (73), limiting highway funding to expected highway revenues (65), and restricting Pell grants to the neediest students (68). In case of size of military, CBO points out that such option will not avert the risk of having a hollow force, just the duration and number of conducted military operations will decrease. However, that alone cannot solve the deficit problem. Among 23 of mandatory spending options totaling up to 1,518 billions of dollars in savings, the largest savings option is converting multiple assistance programs for lower-income people into smaller block grants to states (404), followed by reducing social security benefits for new beneficiaries by 15 percent (188), using an alternative measure of inflation to index social security and other mandatory programs (162), elimination of concurrent receipt of retirement pay and disability compensation for disabled veterans (108), elimination of supplemental security income benefits for children (103), link initial social security benefits to average prices instead of average earnings (58 to 93), elimination the add-in to Pell Grant that is funded with mandatory spending (76). Converting assistance programs for lower-income people block grants to states means that low-income household will depend more on programs designed by state. To reduce social security benefits CBO suggests adjust formula that translates average earnings into benefits, the benefits will be reduced by 3 percent for people 
eligible in 2015, and grow to 15 percent in 2019, thus making some time for people to plan, that especially needed for lower income earners because it is most likely that they did not make savings or sufficient savings. The alternative approach would be to reduce benefits by larger percentages for people with higher benefits or reduce benefits for people eligible in 5-10 years. Among 16 options related to health totaling in up to 2,554 billions of dollars in potential savings, the largest option is imposing caps on federal spending for Medicaid (105 to 606 billions of dollars in savings), followed by reducing tax preferences for employment based health insurance (240 to 537), increasing premiums for parts b and d of Medicare (287), converting medicate to a premium support system (22 to 275), adding a "public Plan" to the health insurance exchanges (158). CBO also suggest 36 options to increase revenue.

While some of those recommendations are already being implemented in one or other way (for example reducing military size and developing chained CPI, that presumes that people choose less expensive substitutes in inflationary environment), and other recommendations present a moral dilemma-how much of social security net must be provided to low-income people and whose responsibility is that, we are still left with entitlement systems that cannot be fixed by half measures and constant unfair adjustments. Like in the case of decreasing benefits by 15 percent to new beneficiaries without consideration of how much fairness compared to past beneficiaries there is, which contradicts the nature of capitalism, where individual efforts and investments are rewarded accordingly, assuming that benefits like taxes are subjects to a free change whenever it is convenient for mostly political reasons, depending on what issue is pressuring at the moment.

$\mathrm{CBO}$ projects noticeable rise in federal spending relative to the size of the economy because of growth in few largest programs (along with growing interest cost): Social Security and healthcare programs (Medicaid, Medicare, the Children's Health Insurance Program, subsidies for health insurance purchased through the exchanges created under the Affordable Care Act). And once again, the aging of the population will be the key driver of spending over the next 25 years.

Because of unsustainability Social Security and Medicare present double burden-for government that needs to find a way to reduce debt and people who will have to pay for governmental neglect paying higher taxes and receiving lower benefits.

Sylvester Schnieber (2012) explains specifically what drove Social Security costs so high: first, ratio of average benefits paid to the recipients and to the average covered earnings of workers paying the payroll taxes; secondly, the ratio of number of beneficiaries to the number of workers supporting the system with their payroll taxes (pp. 16-17). He points out that if the design of Social Security is proper then there will be relationship between earnings subject to payroll tax and benefits paid to retirees. Demographic and retirement behavior should also be studied in order to achieve proper design of the system.

Eugene Steuerle (2014), Institute Fellow and Richard B. Fischer Chair, Urban Institute, in his testimony House Ways and Means subcommittee on Social Security, propose, "Social Security reform is inevitable because of its imbalances" (p. 9). He points out for example that every expansion of the elderly support system requires shorter higher tax contribution time frame for older workers, while the youngest will contribute at that higher rate their entire working lives.

CBO (2010) suggested different options how the long run sustainability of Social Security can be achieved through combination of raising taxes and cutting benefits. Those options fall into five major categories: increases in the Social Security payroll tax, reductions in people's initial benefits, increases in benefits for low earners, increases in the full retirement age, and reductions in the cost-of-living adjustments that are applied to continuing benefits.

In its budget overlook CBO (2014) warns: "Unless substantial changes are made to the major health care programs and Social Security, spending for those programs will equal a much larger percentage of GDP in the future than it has in the past" (p. 5).

Such half measures were implemented in 1983 when Social Security faced a financing problem. Under 1983 amendments to Social Security, followed by National Commission on Social Security Reform endorsed by Ronald Reagan, the tax rates were increased, retirement age was raised, and up to one-half of Social Security benefits were made a potentially taxable income ("Social Security Amendments of 1983-Signed on April 20, 1983," n. d.). Recommendation was made that: "The members of the National Commission believe that the Congress, in its deliberations on financing proposals, should not alter the fundamental structure of the Social Security program or undermine its fundamental principles" ("1983 Greenspan Commission on Social Security Reform," n. d.). However, as concluded earlier, such fundamental principles will not be able to sustain Social Security system. As prognosed by CBO-Social Security surplus will be over soon, and from there on there will 
be an ever growing deficit considering the system remains the same.

\section{Discussion}

Today, the debate over Social Security reform does not come down to actually choosing different options and designs of the system. The biggest problem is proving the necessity of the reform. There is a common belief that Social Security reform is not needed because it does not influence American debt. Such belief is a misconception.

The gross national debt of United States has reached 17,682,532 millions of dollars as of August 2014, out of which 12,671,326 is held by the public ("Treasury Direct," n. d.). Public debt is almost equally divided between foreign investors and other non-federal entities (Federal Reserve System, individuals, corporations, private pensions, banks, insurance companies, state and local governments, etc.) (Agresti, 2011). Of the money owed to foreign investors, the largest are in China and Japan (1,268.4 and 1,219.5 billions of dollars respectively) (United States Treasury Department, 2014). A very popular statement proposing to reduce deficit by «stopping trading with China» is actually a misleading one, considering that the amount is not as big compared to domestic creditors. In addition, many countries (including China, Japan, Russia, etc.) keep increasing holdings in American debt because U.S. security remains to be few of the most financially stable investments. China's economic growth is highly dependent on U.S. dollar as a currency of some of its substantial cash reserves.

The rest of gross national debt, roughly 5 trillion dollars is debt owed to federal entities (so called Intergovernmental Holdings, $\mathrm{IH}$ ), half of which includes Medicare, military retirement, civil service retirement and disability, DoD retiree healthcare (Agresti, 2011). Other half includes Social Security Trust Funds.

Thus America owes most of its debt to itself and its residents (both public debt and IH).

The controversy starts with understanding of IH as entitlement programs trust funds, like Social Security trust funds, that accumulate surplus (as discussed earlier) and thus cannot contribute to the deficit. This understanding is correct; however it does not end there. The reason why IH owns debt is that in the past of surplus of entitlement programs, that very same surplus was used to cover part of the gross national debt, meaning that government borrowed the surplus.

Few important explanations made by Congressional Research Service will clarify. First: the tax revenues are deposited into the U.S. Treasury and are indistinguishable from revenues that come from other sources, "because the assets held by the trust fund are federal government securities, the trust fund balance represents the amount of money owed to the Social Security trust fund by the general fund of the U.S. Treasury. Funds needed to pay Social Security benefits and administrative expenses come from the redemption or sale of federal government securities held by the trust fund." (Nuschler \& Sidor, 2014, p. 1) Second: "When the Social Security trust fund operates with a cash flow deficit, the Treasury can continue to pay benefits at levels scheduled under current law as long as the accumulated balance in the Social Security trust fund is sufficient to cover the cost... When current revenues are not sufficient to pay benefits, however, the U.S. government must raise the funds necessary to honor the redemption of U.S. government obligations held by the Social Security trust fund as they are needed to pay benefits. If there are no surplus governmental receipts, the U.S. government may raise the necessary funds by increasing taxes or other income, reducing other spending, borrowing from the public (i.e., replacing bonds held by the trust fund with bonds held by the public), or some combination of these measures." (Nuschler \& Sidor, 2014, p. 9)

Thus, when accumulated balance of Social Security trust fund will be exhausted, as predicted by CBO, in order to sustain the Social Security benefits, the government will need to borrow from public, and as explained by Congressional Research Service, replace IH debt with debt held by public, which makes American entitlement programs (including Social Security) reform a higher priority in avoiding growing American debt because as explained in previous chapter Social Security program cannot sustain itself in a long term.

In its most recent long term recent outlook, CBO projects that by 2039 federal spending would increase to 26 percent (if laws remain unchanged): federal spending for Social Security and the government's major health care programs will rise to a total of 14 percent of GDP (mostly because of aging of the population, growing spending and expansion of healthcare); government interest payments will grow because federal debt will be larger; spending on everything other that Social Security, healthcare, and net interest payment, will decline 7 percent of GDP by 2039 (smaller share of the economy than at any time since the late 1930s) (CBO, 2014). Overall, by 2039 public debt held by public will exceed 100 percent of GDP, level seen only once before in history of United Stared-after Second World War.

Gregory Mankiw points out that throughout history the primary reason for fluctuations in government debt was 
war, however one large increase in debt (as percentage of GDP) not explained by war the increase that occurred when President Ronald Reagan took the office in 1981, who was envisioned smaller government and lower taxes (Mankiw, 2008a). As Mankiw points out, "yet he found cutting government spending to be more difficult politically than cutting taxes". This statement also applies to today's situation, as no political party is willing to make necessary but politically unpopular adjustments.

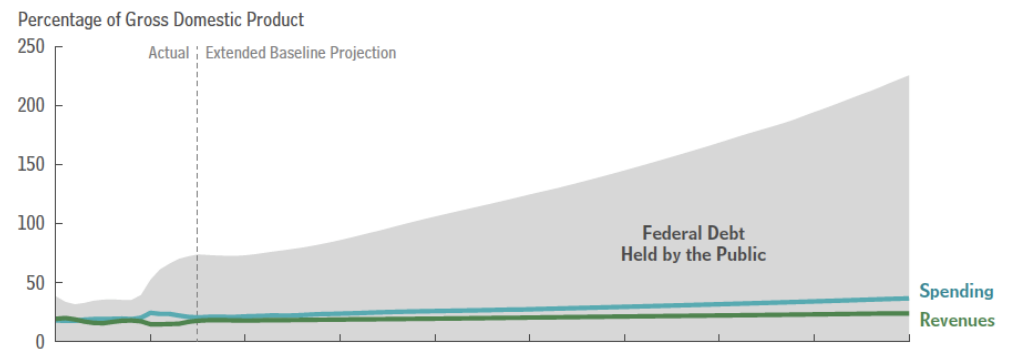

Figure 3. Debt held by the public, total spending, and total revenues, through 2089 (CBO, 2014)

Mankiw also believes that some of the main reasons for rise in spending are Social Security and rising cost of healthcare, such as Medicare and Medicaid (Mankiw, 2008b). Social Security and Medicare provide significant benefits for the elderly population, which grows because of the increased life expectancy, meaning fewer workers to pay taxes that elderly population receives as benefits. Proving Medicare for elderly and Medicaid for poor will force spending increase as the cost of healthcare increases (mainly including new expensive medical advances that extend and improve life).

As most industrial countries U.S. have a substantial debt, its amount essentially does not play as big of a role as a debt-to-GDP ratio. Though as of today this ratio is not as gruesome when it comes to debt in percent of GDP (for example, Japan, Germany, U.K. stay way ahead), it sure will rise if measures are not implemented.

In the past 30 years national debt rose so dramatically as it has not done in previous 200 years of United State history.

One of the most serious reasons to worry about U.S. deficit is its consistency. When unexpected events like war or recession happen-it is natural for government to fall into deficit. However, if the deficit is consistent and the debt is growing it means real dangers for economy and country as a whole: large deficit poses a risk especially in the case of a long-term threat because it becomes less flexible in case it needs to respond to unforeseen events; high deficit over a long time frame can slow economic growth, slowing down the investments, harming nations credit, and creating uncertainty; debt can virtually consume the entire nation-interest payments can outgrow nation's total income and debt can start growing faster than economy as a whole, in order to keep up with that government will need to raise taxes and cut spending, and as the result decreased living standards.

Speaking of fiscal sustainability at the first meeting of National Commission on Fiscal Responsibility and Reform, Ben Bernarke (2010), who served as chairman of the Federal Reserve, in 2010, acknowledged that even though "projected fiscal imbalances associated with the Social Security system are notably smaller than those for federal health programs, they still are significant and thus present an important challenge for policy."

\section{Conclusions}

Governmental fiscal health is a complex topic that cannot be fixed by a single measure. With an undergoing healthcare reform there is a clear understanding that some of the American entitlement programs cannot continue as they are-substantial change must be made. One of those programs is Social Security. The current design of Social Security is projected not to be as functional as originally presumed. All the claims that Social Security would not add to the public debt, are essentially misleading, and if government will not get those long-term entitlement spending under control, the American debt will keep growing without public even knowing about it, paying all their attention unproportionally to the significance of trading with china or defense budget. As argued in the article, while the overall governmental spending are excepted to decrease, Social Security and healthcare spending are expected to increase, sabotaging economy of United Sates by imposing debt potentially larger than country's GDP. In the same time, half-measures, already implemented before, will still keep on failing to sustain the system for one reason or another-whether it is a nonfunctional formula, nonfunctional trust fund, or increased authority of government over peoples retirement savings. At this point there are essentially two solutions if the basic design of Social Security remains the same: raising taxes, that will slow down the economy even more, or 
decreasing benefits thus exposing millions of older and disable people to a poverty. Since the burden most likely will shift towards future generations, social security net will become a major source of injustice in United States. The recession already brought a lot of stress on population, especially younger people entering the workforce. It is highly likely that more stress will be brought on younger Americans in trying to sustain Social Security. Social security is based on the assumption that most people cannot take care of themselves, which is a fair assumption. However Social Security system must be designed with better adjustment to current situation, like life expectancy, more appropriate calculation of benefits, creating more professional investment tools for private pensions, developing pension hybrids that assume that individual can take the responsibility for him or herself, in addition-maybe even changing qualification standards for disability insurance. In any way, there must be significant changes made, either Republican or Democratic party must compromise and both take responsibility for very unpopular political decision that will make a lot of people angry, but that will break a vicious cycle giving some room for long term economic growth in future. Today it is morally more beneficial to talk about providing safety net for lower income families and increasing benefits for elderly, however it is also extremely important to protect younger generation who is already struggling in a highly competitive job market, from higher burden of taxes, because this will lead economy to a bigger recession, which in a big Figure will make a big consequences.

Analyzing what drove countries to their peak and their fall, Paul Kennedy (1987) in his book "The Rise and Fall of Great Powers» points out that ultimately even though history of international affairs has been too frequently a history of warfare "...the differentiated pace of economic growth among the Great Powers ensures that they will go on, rising and falling, relative to each other" (p. 537).

\section{References}

Agresti, J. D. (2011, April 26). National Debt Facts. Just Facts. Retrieved from http://www.justfacts. com/nationaldebt.asp

Altman, N. J. (2009, August 14). President Barack Obama could learn from Franklin D. Roosevelt. Los Angeles Times. Retrieved from http://articles.latimes.com/2009/aug/14/opinion/oe-altman14

Bernarke, B. S. (2010, April 27). Achieving Fiscal Sustainability. Remarks by Ben S. Bernanke Chairman Board of Governors of the Federal Reserve System to the National Commission on Fiscal Responsibility and Reform Washington, D.C. Retrieved from http://www.federalreserve.gov/newsevents/speech/bernanke 20100427a.pdf

Business Owner's Toolkit. (2014, January 13). Understanding Defined Benefit and Defined Contribution Plans. Retrieved from http://www.bizfilings.com/toolkit/sbg/office-hr/managing-the-workplace/understanding -defined-benefit-contribution-plans.aspx

Central Intelligence Agency. (n. d.). The World Factbook. North America: United States. Retrieved August 13, 2014 from https://www.cia.gov/library/publications/the-world-factbook/geos/us.html

Chougule, A. (2014, July 23). CBO: Budget Deficits to Saddle Next Generation with WWII-Era Burden. Forbes. Retrieved from http://www.forbes.com/sites/theapothecary/2014/07/23/cbo-budget-deficits-to-saddle-nextgeneration-with-wwii-era-burden/

Congressional Budget Office. (2010). Social Security Options (CBO Publication No. 4140). Washington, DC: U.S. Government Printing Office. 53. Retrieved from http://www.cbo.gov/sites/default/files/cbofiles/ ftpdocs/115xx/doc11580/07-01-ssoptions_forweb.pdf

Congressional Budget Office. (2013a). The 2013 Long-Term Projections for Social Security: Additional Information (CBO Publication No. 4796). Washington, DC: U.S. Government Printing Office. Retrieved from http://www.cbo.gov/sites/default/files/cbofiles/attachments/44972-SocialSecurity.pdf

Congressional Budget Office. (2013b). Options to Reducing the Deficit 2014 to 2023 (CBO Publication No. 4664). Washington, DC: U.S. Government Printing Office. Retrieved from http://www.cbo.gov/sites/ default/files/cbofiles/attachments/44715-OptionsForReducingDeficit-3.pdf

Congressional Budget Office. (2014). The 2014 Long-Term Budget Outlook (CBO Publication No. 4933). Washington, DC: U.S. Government Printing Office. Retrieved from http://www.cbo.gov/sites/default/files/ cbofiles/attachments/45471-Long-TermBudgetOutlook_7-29.pdf

Erceg, C. J., \& Levin, A. (2013, April 9). Labor Force Participation and Monetary Policy in the Wake of the Great Recession, 12-13. Retrieved from https://www.bostonfed.org/employment2013/papers/Erceg_Levin Session1.pdf

John, D. C. (2005). How today's Social Security Works. Executive Summary Backgrounder by the Heritage Foundation, 1827, 4. 
Joint Select Committee on Deficit Reduction. (2011, November 21). Statement from Co-chairs of the Joint Select Committee on Deficit Reduction (Press Release). Retrieved from http://cybercemetery.unt.edu/archive/ deficit/20120113174936/http://www.deficitreduction.gov/public/index.cfm/2011/11/statement-from-co-chai rs-of-the-joint-select-committee-on-deficit-reduction

Kennedy, P. (1987). The Rise and fall of Great Powers (p. 537). Random House, Inc.

Khimm, S. (2011, November 15). All the super-committee proposals (and counterproposals) in one post. The Washington Post. Retrieved from http://www.washingtonpost.com/blogs/wonkblog/post/all-thesupercommittee-proposals-and-counterproposals-in-one-post/2011/11/15/gIQAUepEPN_blog.html

Mankiw, N. G. (2008a). Principles of Macroeconomics (5nd ed., pp. 288-289). Cengage Learning.

Mankiw, N. G. (2008b). Principles of Microeconomics (5nd ed., pp. 246-248). Cengage Learning.

Nichols, A., \& Lindner, S. (2013, July). Why are Fewer People in the Labor Force during the Great Recession? Urban Institute. Brief, 16, 4.

Nuschler, D., \& Sidor, G. (2014, July 31). Social Security: The Trust Fund, 1, 9. Congressional Research Center.

Romano, R. (2014, January 15). U.S. Unemployment: Retirees Are Not The Labor Exodus Problem. Forbes. Retrieved from http://www.forbes.com/sites/realspin/2014/01/15/u-s-unemployment-retirees-are-not-the -labor-exodus-problem/

Schieber, S. J. (2012). The Predictable Surprise: The Unraveling of the U.S. Retirement System (pp. 5-6, 10-11, 16-17). Oxford University Press.

Social Security Administration. (n. d.). 1983 Greenspan Commission on Social Security Reform. Retrieved from http://www.ssa.gov/history/reports/gspan5.html

Social Security Administration. (n. d.). Social Security Amendments of 1983-Signed on April 20, 1983. Retrieved from http://www.ssa.gov/history/1983amend.html

Stein, S. (2011, September 15). Obama Won't Include Social Security Reform In Recommendations To Super Committee. Huffington Post. Retrieved from http://www.huffingtonpost.com/2011/09/15/obama-socialsecurity_n_964175.html

Steuerle, C. E. (2014, July 2014). What Every Worker Needs to Know About an Unreformed Social Security System. Statement before the Subcommittee on Social Security Committee on Ways and Means United States House of Representatives. Retrieved from http://waysandmeans.house.gov/uploadedfiles/7_29_14 _ss_testimony_eugene_steuerle.pdf

Treasury Direct. (n. d.). The Debt to the Penny and Who Holds It. Retrieved August 5, 2014 from http://www.treasurydirect.gov/NP/debt/current

United States Census Bureau. (n. d.). Population Estimates: National Characteristics: Vintage 2013 (statistics). Retrieved August 2, 2014 from http://www.census.gov/popest/data/national/asrh/2013/index.html

United States Census Bureau. (n. d.). Population Estimates: Pre-1980: National Tables (statistics). Retrieved August 2, 2014 from http://www.census.gov/popest/data/historical/pre-1980/index.html

United States Department of Labor. (2013). Employment Labor Projections (statistics). Retrieved August 2, 2014 from http://www.bls.gov/emp/ep_table_303.htm

United States Department of Labor. (n. d.). Employee Benefits (statistics). Retrieved August 23, 2014 from http://www.bls.gov/ncs/ebs/benefits/2013/ownership/private/table02a.htm

United States Department of Labor. (n. d.). Labor Force Participation Rate 1977 to 2014 (statistics). Retrieved August 2, 2014 from http://data.bls.gov/timeseries/LNS11300000

United States Treasury Department. (2014, August 15). Major Foreign Holders of Treasury Securities (statistics). Retrieved August 20, 2014 from http://www.treasury.gov/ticdata/Publish/mfh.txt

Weissmann, J. (2012, May 31). Surprise! The U.S. Is Stealing Jobs From China. The Atlantic. Retrieved from http://www.theatlantic.com/business/archive/2012/05/surprise-the-us-is-stealing-jobs-from-china/257904/

White House. (2010, May). National Security Strategy, 28-32 Retrieved from http://www.whitehouse.gov/sites/ default/files/rss_viewer/national_security_strategy.pdf

White House. (n. d.). Fiscal Year 2015. Historical Tables: Budget of the U.S. Government (statistics). Retrieved July 25, 2014 from http://www.whitehouse.gov/sites/default/files/omb/budget/fy2015/assets/hist.pdf

\section{Copyrights}

Copyright for this article is retained by the author(s), with first publication rights granted to the journal.

This is an open-access article distributed under the terms and conditions of the Creative Commons Attribution license (http://creativecommons.org/licenses/by/3.0/). 